\title{
ENHANCING COMMUNITY ENVIRONMENTAL AWARENESS THROUGH INDOOR AIR QUALITY WORKSHOP
}

\author{
R.A. Vesitara Kencanasari ${ }^{1}$, Usep Surahman ${ }^{2}$, Asep Yudi Permana ${ }^{3}$, \\ Hari Din Nugraha ${ }^{4}$ \\ 1,2,3 Universitas Pendidikan Indonesia, Bandung, Indonesia \\ 4 Universitas Subang \\ Corresponding author: ra.vesitara@upi.edu, usep@upi.edu, yudi.permana@upi.edu, \\ haridinnugraha@unsub.ac.id
}

\author{
Article History: \\ Received: 28 November Revised: 9 December Accepted: 16 December Available online: 18 December \\ $2020 \quad 2020 \quad 2020 \quad 2020$
}

\begin{abstract}
This research is motivated by the poor air quality in the room at home that can cause Sick Building Syndrome (SBS). The purpose of this research is to increase public awareness of the environment through indoor air quality workshops, with a Pre-Experimental method and One Group Pre-Test Post-Test research design. The sample in this study was Pasteur RW6, Sukajadi District at Bandung City, which was selected based on criteria including non slum areas, as well as high community participation. The results showed that the level of public awareness, knowledge, attitudes, and actions on air quality in the room before the Workshop was in the medium category. Then it increased after the Workshop, which was on a relatively moderate increase in knowledge. This can be seen from the majority of people who already know the importance of indoor air quality, but the knowledge of specific components that affect indoor air quality is still not understood. Whereas attitudes and actions experienced a relatively small increase due to the knowledge gained in the Workshop not being implemented in the form of real attitudes and actions in daily life because people's habits are difficult to change.
\end{abstract}

Keywords - Environmental Awareness, Indoor Air Quality, Workshop, Community Awareness

\section{INTRODUCTION}

Poor air quality in the room is a predisposing factor for the occurrence of symptoms of illness and even death, so it requires quality standards related to this. Quality standards regarding air quality in the room include the level of chemical and biological compounds in the room including temperature, humidity, and other factors (Takigawa et al., 2009; Vesitara et al., 2019). One example, based on research shows that good air quality in the room has a humidity percentage of around $40-60 \%$. If the percentage of humidity is higher than the standard, it will trigger the growth of allergenic fungi (Citraswari, et al., 2015). Then, temperatures that are too high or too low in the room result in uncomfortable conditions and can affect health. In addition to taking into account the standard air quality standards in the room, other research results also state that good indoor air quality can be achieved and maintained by taking into account the ventilation system of the room, design, shape of the room, pollutant management, and awareness of residents of the house (Fitria, 2008). So based on this, it is important to provide a safe, healthy and productive environment in maintaining air quality in the room

In fact, many residential units have indoor air quality that does not meet these standards. Besides being marked by high mortality rates in each country, it is also supported by findings regarding indoor quality related to the physical condition of buildings such as air ventilation 
problems in residential homes (Kelly \& Fussell, 2019; Takaoka, Suzuki, \& Norbäck, 2016). In an effort to minimize mortality and prevent the spread of various types of SBS required learning that can be accepted by the community to get knowledge about air quality in the room. One form of learning is through workshops. Workshop is a form of education in society that functions to take action on issues about the future of society (Jungk \& Muller, 1987).

In this research workshop aims to increase public environmental awareness about indoor air quality. Environmental awareness can be interpreted as an attitude of environmental risk from human behavior needs to be improved because it plays an important role for survival (Kencanasari, et al., 2019)(Kencanasari et al., 2020). Environmental awareness is also referred to as a form of concern for environmental problems and the active involvement of individuals in an environmental organization (Mei, et al., 2016). Environmental awareness has a tendency to react to environmental problems in certain ways (Ham et al., 2015) (Permana et al., 2020). Environmental awareness is built on the basis of knowledge, attitudes and subsequently is applied through action. Environmental awareness must be implemented by conducting socialization about the importance of protecting the environment. Environmental awareness consists of three (3) components, namely knowledge / skills, attitudes and actions/ behaviors (Awan \& Abbasi, 2013). The three components of environmental awareness are used to test environmental awareness of what is happening in the environment (Aminrad, Sayed Zakaria, \& Hadi, 2011).

Based on this rationalization, there has been no research that examines increasing public awareness through a workshop on indoor air quality. Therefore this research focuses on studying increasing public awareness of indoor air quality through workshops. Fig. 1 below is a picture of the State of The Art of this study.

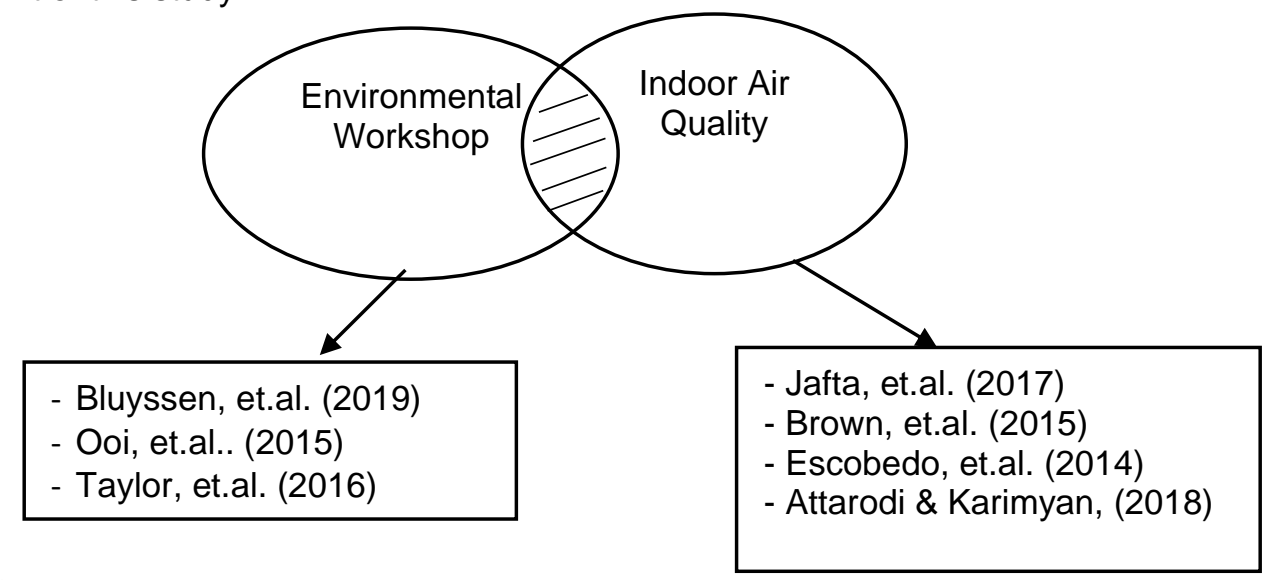

Figure. 1 State of the art of enhancing community environmental awareness through indoor air quality workshop

\section{METHODOLOGY}

The research method used in this study is a quantitative method with a Pre-Experimental approach. This method was chosen because the researcher wanted to find a relationship between the Workshop variables and the community's awareness of air quality in the residence, after being given treatment in the form of a Workshop on air quality in the residence. So that they can find the right learning model for the workshop in increasing community knowledge (Nugraha, et al., 2020). In the study using only one group as an experimental group without a control group. The experimental group was first given a first-stage test (Pre-Test) with a questionnaire instrument, then subsequently given treatment (treatment) in the form of a Workshop and finally the second stage of the test (Post-Test) was again carried out using the same questionnaire instrument.

\section{Find the right learning model for workshops in increasing public knowledge}

The population in this study is the city of Bandung. The sampling technique in this study uses a purposive sampling technique, which is the process of taking a sample by determining specific conditions or criteria that are consistent with the research objectives. These criteria are non-slum areas, high community participation, namely mothers and heads of households. This was chosen because the occupants of the house have an important role in the process of sanitation in the home related to the activities and habits carried out while in the house. High community participation was also chosen because the community will be easily invited to work together in 
research both in measurement and questionnaire surveys. The non-slum area was chosen because the village was not the focus of the government (through the City without Slums Program / KOTAKU) and the Department of Housing and Settlement, Land, and Parks (DPKP3) of Bandung City in terms of development and infrastructure because this research was a secondary need for the community after the facilities and infrastructure are met. The results of field observations that have been made, Pasteur RW6 Village, Sukajadi District was chosen as a research sample. This district was chosen because it represented the areas that were most suitable for high community participation by the existence of the GEMAS (Healthy Community Movement). This community is an organization engaged in waste management and environmental improvement, even this movement won the award "Cleanliness and Waste Management" at the Sukajadi District level. Data analysis using the tendency test, Paired T Test, and N-Gain test to see an increase in community awareness.

\section{RESULT AND DISCUSSION \\ Validity and Reliability Test}

Validity test aims to see the validity of the instrument of the level of environmental awareness of the public about air quality in the room. The instrument is divided into 3 (three) parts, the first instrument of knowledge is tested using the SPSS25 measuring instrument with the Split Half Level method. The validity test was then consulted on the critique price table of $r$ Product Moment at a $95 \%$ confidence level with a value of $\mathrm{N}=30$, then $\mathrm{r}$ table $=.361$ was obtained. From the test results for the knowledge indicator obtained 12 invalid statement items and 26 valid statement items. The second instrument about attitude was tested using the SKALO measurement tool using the formula of the coefficient of reproducibility and scalability. The test was then consulted with the reproducibility coefficient $=.90$ and the scalability coefficient $=.60$, resulting in 0 error statements and 26 valid statements. The third instrument was carried out using the SPSS25 measuring instrument distributed to 30 respondents. The validity test was then consulted on the critique price table of $r$ Product Moment at a 95\% confidence level with a value of $N=30$, then r_table $=.361$ was obtained. From the test results for the knowledge indicator 5 items were invalid questions and 21 questions were valid. The invalid questions are then corrected.

The next step after the validity test is the reliability test. The reliability test results using SPSS25 note that all instruments are reliable. This is evidenced by the Cronbach's Alpha value for the knowledge variable above .7, and the Kuder Ridchardson 21 value for the attitude variable above .2, and the Cronbach's Alpha value for the action variable above .7.

\section{Research Procedure}

This research was conducted in four stages, as follows:

1. The preparation phase, activities carried out at the preparation stage as follows:

1) Conduct a literature review on environmental workshops on air quality in the room.

2) Determine the research topic and subject.

3) Arranging Workshop plan activities that are place, Workshop time, and learning resources.

4) Arrange Workshop modules that contain teaching material that will be given to Workshop participants on the importance of maintaining air quality in a residential home, related to physical, biological, and chemical factors that affect air quality in a residential home.

5) Develop a questionnaire instrument / questionnaire to find out public awareness about air quality in homes before and after the Workshop is conducted.

6) Respondents from this survey are workshops that are mothers and household heads of residents.

7) Carry out instrument testing Conduct data validation test by conducting validity and reliability tests

2. The implementation phase, activities carried out at the implementation stage are:

1) Conducting Workshop activities twice, in detail explained in table below.

Table 1

Stages of Implementation of Workshop Activities

\begin{tabular}{|c|c|c|c|}
\hline Activity & $\begin{array}{l}\text { Description } \\
\text { of Workshop }\end{array}$ & Time & Resource \\
\hline \multirow{3}{*}{$\begin{array}{l}\text { First } \\
\text { Workshop, } \\
\text { September } \\
21^{\text {st }}, 2019\end{array}$} & Opening: & & \\
\hline & $\begin{array}{l}\text { a. Fill out the } \\
\text { attendance }\end{array}$ & $15.30-15.30$ & $\begin{array}{l}\text { Workshop } \\
\text { participants }\end{array}$ \\
\hline & b. Foreword from the & 15.30 .15 .35 & Researcher \\
\hline
\end{tabular}




\begin{tabular}{|c|c|c|c|}
\hline Activity & $\begin{array}{l}\text { Description } \\
\text { of Workshop }\end{array}$ & Time & Resource \\
\hline & presenter & & \\
\hline & $\begin{array}{l}\text { c. Message from the } \\
\text { Chairman of RW } 6 \\
\text { Pasteur }\end{array}$ & $15.35-15.40$ & Mr. Ilya \\
\hline & $\begin{array}{lr}\text { d. Explain } & \text { the } \\
\text { purpose } & \text { and } \\
\text { objectives } & \text { of } \\
\text { Workshop } & \end{array}$ & $15.40-15.45$ & Researcher \\
\hline \multicolumn{4}{|c|}{ Core Activities: } \\
\hline & $\begin{array}{l}\text { a. Carry out the Pre- } \\
\text { Test }\end{array}$ & $15.45-16.00$ & Researcher \\
\hline & $\begin{array}{l}\text { b. Provide Workshop } \\
\text { materials }\end{array}$ & $16.00-16.05$ & \multirow{4}{*}{ Researcher } \\
\hline & $\begin{array}{l}\text { c. Explain about the } \\
\text { importance of } \\
\text { Indoor Air Quality } \\
\text { at dwelling house }\end{array}$ & $16.00-16.30$ & \\
\hline & $\begin{array}{l}\text { d. Question, answer, } \\
\text { and discussion }\end{array}$ & $16.30-16.45$ & \\
\hline & $\begin{array}{l}\text { e. Distributing plants } \\
\text { as a neutralizing } \\
\text { air in the room by } \\
\text { doing a quiz }\end{array}$ & $16.45-16.55$ & \\
\hline & \multicolumn{3}{|l|}{ Closing: } \\
\hline & $\begin{array}{l}\text { a. Summing up the } \\
\text { Workshop material }\end{array}$ & $16.55-17.00$ & Researcher \\
\hline & $\begin{array}{l}\text { b. Concluding } \\
\text { remarks from the } \\
\text { chairman of RW } 6 \\
\text { Pasteur }\end{array}$ & $17.00-17.05$ & Mr. Ilya \\
\hline & $\begin{array}{l}\text { C. Closing the } \\
\text { Workshop with a } \\
\text { prayer }\end{array}$ & $17.05-17.10$ & Mr. Ilya \\
\hline \multirow{10}{*}{$\begin{array}{l}\text { Second } \\
\text { Workshop, } \\
\text { October } \\
3^{\text {rd }, 2019}\end{array}$} & \multicolumn{3}{|l|}{ Opening: } \\
\hline & $\begin{array}{l}\text { a. Fill out the } \\
\text { attendance }\end{array}$ & $11.00-11.05$ & $\begin{array}{l}\text { Workshop } \\
\text { participants }\end{array}$ \\
\hline & $\begin{array}{l}\text { b. Message from the } \\
\text { Chairman of RW } 6 \\
\text { Pasteur }\end{array}$ & $11.00-11.15$ & Mr. Ilya \\
\hline & $\begin{array}{l}\text { c. Explain the } \\
\text { purpose and } \\
\text { objectives of the } \\
\text { second Workshop }\end{array}$ & $11.05-11.10$ & Researcher \\
\hline & \multicolumn{3}{|l|}{$\begin{array}{l}\text { Core } \\
\text { Activities: }\end{array}$} \\
\hline & $\begin{array}{l}\text { a. Provide Workshop } \\
\text { materials }\end{array}$ & $11.10-11.15$ & Researcher \\
\hline & $\begin{array}{l}\text { b. Explain about the } \\
\text { importance of } \\
\text { Indoor Air Quality } \\
\text { at dwelling house }\end{array}$ & $11.10-11.40$ & \\
\hline & and community & & Researcher \\
\hline & $\begin{array}{l}\text { participation to } \\
\text { maintaining indoor } \\
\text { air quality }\end{array}$ & & \\
\hline & c. Question & $11.40-12.00$ & \\
\hline
\end{tabular}




\begin{tabular}{|c|c|c|c|}
\hline Activity & $\begin{array}{l}\text { Description } \\
\text { of Workshop }\end{array}$ & Time & Resource \\
\hline & $\begin{array}{lr}\text { answer } & \text { and } \\
\text { conducting } & \text { case } \\
\text { studies } & \end{array}$ & & \\
\hline & $\begin{array}{l}\text { d. Distributing plants } \\
\text { as a neutralizing } \\
\text { air in the room by } \\
\text { doing a quiz }\end{array}$ & $12.00-12.10$ & \\
\hline & Closing: & & \\
\hline & $\begin{array}{l}\text { a. Concludes the } \\
\text { workshop material }\end{array}$ & 12.10 .12 .15 & Researcher \\
\hline & $\begin{array}{l}\text { b. Concluding } \\
\text { remarks from the } \\
\text { chairman of RW } 6 \\
\text { Pasteur }\end{array}$ & $12.15-12.20$ & Mr. Ilya \\
\hline & $\begin{array}{l}\text { c. Closing the } \\
\text { Workshop with a } \\
\text { prayer }\end{array}$ & $12.20-12.05$ & Mr. Ilya \\
\hline $\begin{array}{l}\text { Post-Test, } \\
\text { October } \\
10-14^{\text {th }} \\
2019\end{array}$ & $\begin{array}{l}\text { Conducting } \\
\text { Post-Test } \\
\text { door to door }\end{array}$ & $10.00-15.00$ & Researcher \\
\hline
\end{tabular}

3. The final stage, the activities carried out at the final stage are:

1) Conduct data processing from the results of a questionnaire survey.

2) Conduct data analysis using trend test, Paired T Test, and N-Gain test.

3) Making the results of the final report in accordance with the formulation of the problem that is seeing a picture of the condition of the air quality in the room, the level of public awareness before and after the Workshop.

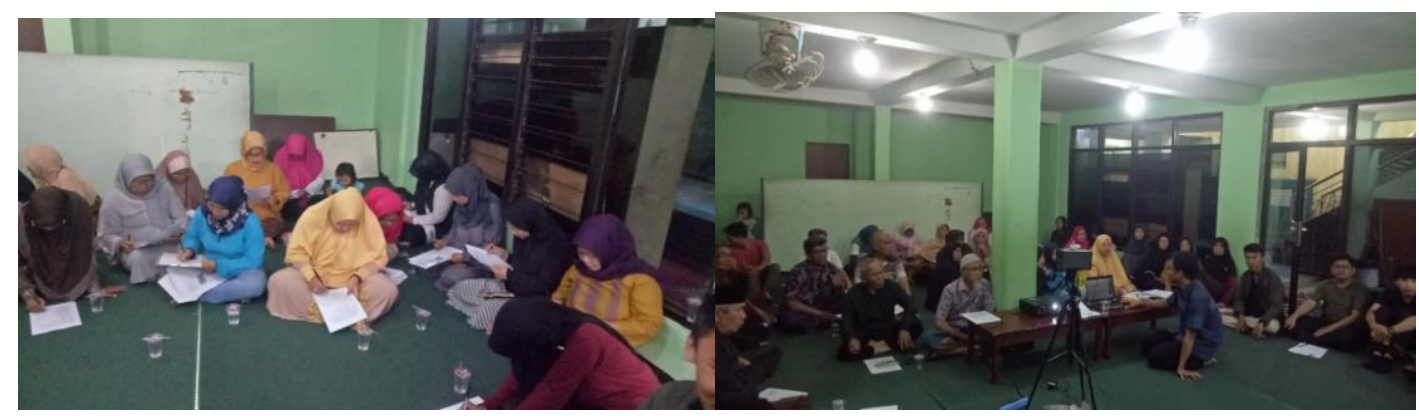

(a)

(b)

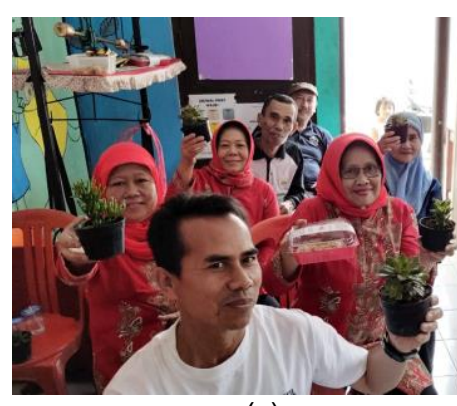

(c)

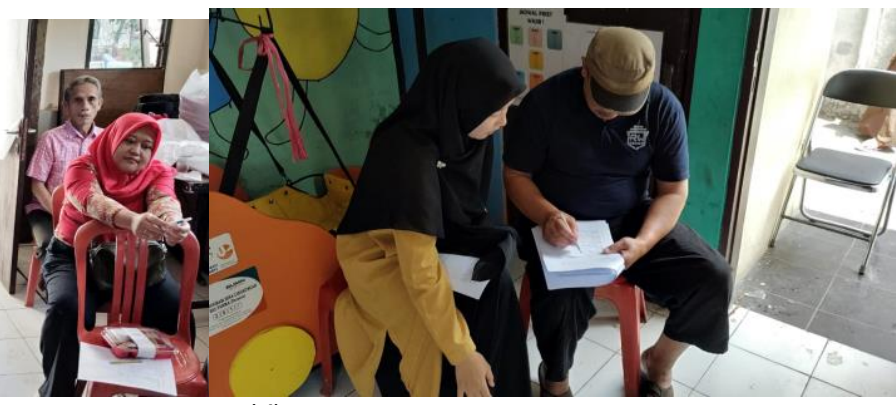

(d)

Figure 2. (a) Pre-test; (b) First workshop; (c) Second workshop and plant giving; (d) Post-test Source: Researcher Documentation

\section{N-Gain Knowledge, Attitudes and Action about Indoor Air Quality Before Workshop}

Knowledge variable is measured through an instrument consisting of 38 statement items with a Likert Scale consisting of 4 alternative answers. Based on Table 2 the most frequency is in 
the range of scores $105 \leq X<121$ with a total of 18 people $(60 \%)$, the second highest frequency is in the range of scores $<105$ which is 10 people $(33 \%)$, and the least is in the range of scores $\geq$ 121 , totaling 2 people $(7 \%)$. From the results of community answers obtained an average value $=$ 108 , it can be concluded that the tendency of the knowledge variable is in the equation $105 \leq X$ $<121$ or is in the medium category with a percentage of $60 \%$ and frequency 18 .

Table 2

Distribution of Knowledge Variable Categories (Pre-Test)

\begin{tabular}{llll}
\hline \multirow{2}{*}{ Score } & \multicolumn{2}{l}{ Frequency } & \\
\cline { 2 - 3 } & Frequency & $\%$ & \\
\hline$X \geq 121$ & 2 & $7 \%$ & High \\
$105 \leq X<121$ & 18 & $60 \%$ & Medium \\
$X<105$ & 10 & $33 \%$ & Low \\
\hline Total & 30 & $100 \%$ & \\
\hline
\end{tabular}

Table 3 below shows that the frequency of attitude variables is most in the range of scores $16 \leq X<19$ totaling 12 people $(40 \%)$, the second highest frequency is in the range of scores $\geq 19$ totaling 11 people (37\%), and the lowest frequency is at the range of scores $<16$ totaled 7 people $(23 \%)$. Attitude variable is measured using the Guttman Scale with a total of 26 statement items consisting of 2 alternative answers. Based on the results of respondents' answers regarding attitudes about air quality in the room obtained an average value $=17$, it can be concluded that the tendency of the attitude variable is in the equation $16 \leq X<19$ which is classified as medium category with a percentage of $40 \%$ and frequency 12 .

Table 3

Distribution of Attitude Variable Categories (Pre-Test)

\begin{tabular}{llll}
\hline \multirow{2}{*}{ Score } & \multicolumn{2}{l}{ Frequency } & \\
\cline { 2 - 4 } & Frequency & $\%$ & \\
\hline$\geq 19$ & 11 & $37 \%$ & High \\
$16 \leq X<19$ & 12 & $40 \%$ & Medium \\
$<16$ & 7 & $23 \%$ & Low \\
\hline Total & 30 & $100 \%$ & \\
\hline
\end{tabular}

Table 4 below shows the frequency of the most action variables is in the range of scores $60 \leq X<78$ totaling 13 people $(43 \%)$, the second largest is in the range of scores $\geq 78$ totaling 12 people $(40 \%)$, and the lowest frequency is in the range a score of $<60$ totaling 5 people $(17 \%)$. The action variable is measured using a Likert scale with 26 question items, consisting of 4 alternative answers. The results obtained from the data obtained the average value of respondents' answers regarding actions on air quality in the room $=61$, it can be concluded that the tendency of the action variables are in the equation $60 \leq X<78$ or are in the medium category with a percentage of $43 \%$ and frequency 13.

Table 4

Distribution of Action Variable Categories (Pre-Test)

\begin{tabular}{llll}
\hline \multirow{2}{*}{ Score } & \multicolumn{2}{l}{ Frequency } & \\
\cline { 2 - 4 } & Frequency & $\%$ & Category \\
\hline$\geq 78$ & 12 & $40 \%$ & High \\
$60 \leq X<78$ & 13 & $43 \%$ & Medium \\
$<60$ & 5 & $17 \%$ & Low \\
\hline Total & 30 & $100 \%$ & \\
\hline
\end{tabular}




\section{N-Gain Knowledge, Attitudes and Action about Indoor Air Quality After Workshop}

The level of public awareness about air quality in the room after the workshop (Post-Test) is presented in three categories, namely knowledge, attitudes, and actions. In more detail explained as follows. Based on Table 5, it can be seen that after the Workshop, the level of public awareness in terms of knowledge is in the medium category with 11 people $(37 \%)$. In the high category there are 10 people (33\%) and less categories are 9 people $(30 \%)$. From the Post-Test results obtained an average value of answers $=118$, it can be concluded that the level of community knowledge is in the equation $114 \leq X<125$ or in the medium category.

Table 5

Distribution of Knowledge Variable Categories (Post-Test)

\begin{tabular}{llll}
\hline \multirow{2}{*}{ Score } & Frequency & & \\
\cline { 2 - 4 } & Frequency & $\%$ & Category \\
\hline$X \geq 125$ & 10 & $33 \%$ & High \\
\hline $114 \leq X<125$ & 11 & $37 \%$ & Medium \\
\hline$X<114$ & 9 & $30 \%$ & Low \\
\hline Total & 30 & $100 \%$ & \\
\hline
\end{tabular}

Based on Table 6, it can be seen that after the Workshop, the level of public awareness in terms of attitudes is mostly in the medium category, with 12 people $(40 \%)$. In the high category there were 11 people $(37 \%)$ and 7 people $(23 \%)$ in the poor category. From the Post-Test results obtained an average value of answers $=17$, it can be concluded that people's attitudes about air quality in the room are in the equation $16 \leq X<19$ or are in the medium category.

Table 6

Distribution of Attitude Variable Categories (Post-Test)

\begin{tabular}{llll}
\hline \multirow{3}{*}{ Score } & \multicolumn{2}{l}{ Frequency } & \\
\cline { 2 - 4 } & Frequency & $\%$ & Category \\
\hline$X \geq 19$ & 11 & $37 \%$ & High \\
\hline $16 \leq X<19$ & 12 & $40 \%$ & Medium \\
\hline$X<16$ & 7 & $23 \%$ & Low \\
\hline Total & 30 & $100 \%$ & \\
\hline
\end{tabular}

Based on Table 7, it can be seen that after the Workshop, the level of public awareness in terms of action is mostly in the medium category, with 14 people $(47 \%)$. Then in the less category there are 9 people (30\%) and the high category there are 7 people $(23 \%)$. From the Post-Test results obtained an average value of answers $=80$, it can be concluded that people's action about air quality in the room are in the equation $75 \leq 80<88$ or are in the medium category.

Table 7

Distribution of Action Variable Categories (Post-Test)

\begin{tabular}{llll}
\hline \multirow{3}{*}{ Score } & Frequency & & \\
\cline { 2 - 4 } & Frequency & $\%$ & Category \\
\hline$X \geq 88$ & 7 & $23 \%$ & High \\
\hline $75 \leq X<88$ & 14 & $47 \%$ & Medium \\
\hline$X<75$ & 9 & $30 \%$ & Low \\
\hline Total & 30 & $100 \%$ & \\
\hline
\end{tabular}




\section{Paired Sample T-Test}

Table 8 below shows the results of the test of the relationship between the two data / variable relationships Pre-Test \& Post-Test. Based on the above output, the knowledge variable correlation value is .501 with a significance value of .005 . Then it can be concluded that there is a relationship between the variable Pre-Test and Post-Test. The correlation value on the attitude variable is .430 with a significance level of .018 , it shows that there is a relationship between the Pre-Test and Post-Test variables. Next to the action variable the correlation value is .540 with a significance value of .002 . Because the significance value is $.002<$ probability .05 , it can be said that there is a relationship between the Pre-Test \& Post-Test variables. From the results of the calculation of the Paired Sample T Test, it can be concluded that the three variables namely knowledge, attitudes, action have a significant correlation between Pre-Test and Post-Test, this is indicated by the significance value that meets the requirements, namely < probability value of .05 .

Table 8

Paired Samples T-Test

\begin{tabular}{lllll}
\hline \multirow{2}{*}{ Knowledge } & & $\mathrm{N}$ & Correlation & Sig. \\
\cline { 2 - 5 } Attitude & $\begin{array}{l}\text { Pre-Test \& } \\
\text { Post-Test }\end{array}$ & 30 & .501 & .005 \\
\cline { 2 - 5 } Action & $\begin{array}{l}\text { Pre-Test \& } \\
\text { Post-Test }\end{array}$ & 30 & .430 & .018 \\
\cline { 2 - 5 } & $\begin{array}{l}\text { Pre-Test \& } \\
\text { Post-Test }\end{array}$ & 30 & 0,540 & .002 \\
\hline
\end{tabular}

\section{Discussion}

The results of testing the tendency of the level of public awareness in terms of knowledge, attitudes and actions before being given treatment are in the medium category. More specifically the knowledge of the community is proven by the results of the Pre-Test which shows that most of the people agreed about the importance of air quality in the room. In the indicators of factors that influence the quality of indoor air, most people also already know this, but for the knowledge of the components that affect the quality of indoor air is still lacking. For example, many people consider putting plants indoors as a negative effect on indoor air, even though placing plants indoors can help neutralize indoor air pollution (Aini Jasmin, Noorizan, Suhardi, Murad, \& Ina, 2012; Brilli et al., 2018). Another example is that many people assume that opening a window in the morning increases the risk of bacteria entering, even though opening a window in the morning can help kill airborne contaminants in the house, as well as exchanging air from inside and out of the house (Siswanti \& Wijayanti, 2018; Yao \& Zhao, 2017)(Permana, Wijaya, et al., 2020).

The level of public awareness in terms of attitude variables are in the medium category. This is evidenced by the results of the Pre-Test in terms of the attitude that the community has shown an attitude that considers air quality in the room important for the health of residents. Public attitudes tend to avoid the factors that affect the quality of indoor air to be bad. The findings in the field also indicate that there are still some people who do not have a caring attitude towards cleanliness in the house, one of which is shown in the attitude of the people who claim not to clean household furniture, so that dust will accumulate and cause contaminants in the air inside the house. This will have an impact on health, for example impacts that are directly exposed to the skin irritation, upper respiratory tract disorders (sneezing, coughing, colds). Other findings show that the community lacks a caring attitude towards bathroom cleanliness and neglect of leaking house conditions, triggering the growth rate of mold in the room (Lu, Deng, Li, Sundell, \& Norbäck, 2016; Takaoka et al., 2016; Utami, Rusmiati, Rokhmalia, \& Suprijandani, 2017).

The level of public awareness about indoor air quality in terms of the action variable is also in the medium category. Community actions or behavior are in accordance with behaviors that reflect the importance of indoor air quality. Most people have left the indoor and outdoor factors that can affect air quality to be bad, it is also accompanied by environmental care actions by avoiding components that can affect air quality in the room in everyday life. One of them is evidenced by the findings in the field that most people already have the habit of opening windows inside the house in exchange for air inside and outside the room, the habit of cleaning the room inside the house and the habit of cleaning the environment around the house. But there are still 
some people who also show less concern about the factors that can affect air quality in the room, one of them is the consideration of using chemical products such as air freshener, insecticide, and laundry deodorizer. The impact arising from the use of these chemical products can result in increased levels of VOCs in indoor air. Because the chemical compounds in air freshener have a content that is harmful to health if used in the long run. Although the short-term effects of the disease cannot be seen, the long-term effects of the use of these chemicals will be felt later (Kim et al., 2018; Trantallidi et al., 2015).

Based on the findings, other factors in the Formaldehyde indicator show that the Pasteur community also does not routinely wash pillowcases, sheets, curtains, and lay the mattress in the sun. This is due to the lack of discipline in the community to take the time to clean up household attributes. This action is reasonable because although the majority are housewives who spend more time at home, they are less concerned about the dangers of formaldehyde. In addition, the factor of lack of land for drying clothes causes the people to be lazy to hang clothes outside the house.

Public knowledge after being given treatment through the Workshop experienced a relatively moderate increase of $33 \%$. The increase in knowledge was due to the curiosity and concern for the environment of some Workshop participants, but there were still some Workshop participants who showed no interest in the Workshop being held. There are also other factors, namely the relatively short duration of the Workshop, the limited location of the Workshop, and the community's lack of concern for the quality of the air inside the house.

The attitudes and actions of the people after being given treatment through the Workshop have increased with a low percentage of $2 \%$ and $11 \%$. The knowledge gained by some people from the Workshop results was not implemented in the form of real attitudes and actions in daily life, other than that it was influenced by factors that were difficult to change and the community's indifference to air quality in the room.

Attitude is a factor that is difficult to change during the learning process because attitudes are formed at birth (Mat Said, Ahmadun, Paim, \& Masud, 2003; Utari, 2011). While in the aspect of behavior (action) requires more physical coordination so that it is more practiced rather than learned (Utari, 2011). In this case, for example, in the attitude of cleaning furniture in the Workshop, an ideal plan or schedule is made to clean furniture. As for actions, one of the things that can and has been done is the provision of plants that can neutralize the air in the room to Workshop participants.

Increasing public awareness about air quality must be grown from small things ranging from light activities to cleaning household appliances to opening windows every time they carry out other work activities. Furthermore, the hope of this research can have a long-term impact on changing attitudes and more concrete actions. Because the knowledge of air quality is judged from the results that show a moderate category, it's just that to implement it must be really implemented. Creating a healthy home environment as a step to maintain indoor air quality is the responsibility of every family member. The role of family members in implementing knowledge in the form of attitudes and actions for indoor air quality has a good impact on the health of residents of the house, so that it can create a sustainable life.

\section{Conclusion}

The level of public awareness prior to the Workshop is that knowledge indicators tend to be in the medium category, for attitude indicators it also tends to be in the medium category, and the action indicators are also in the medium category. In addition, there was an increase in public awareness of air quality after a relatively small workshop. This is reasonable, for the knowledge factor most people already have knowledge about the importance of indoor air quality, but for knowledge about specific components that affect indoor air quality is still lacking. While the attitude and action factors are caused by the knowledge gained in the Workshop which is not implemented in the form of real attitudes and actions in daily life because people's habits are difficult to change. Physical repair of buildings and the environment will be far easier to do in improving environmental conditions than having to change people's habits.

\section{Acknowledge}

The author acknowledges the RW 6 community Pasteur, Sukajadi, Bandung, and the chief of RW 6 Pasteur District, thank you for the cooperation in completing this research. 


\section{References}

Aini Jasmin, G., Noorizan, M., Suhardi, M., Murad, A. G., \& Ina, K. (2012). The use of plants to improve indoor air quality in small office space. Pertanika Journal of Social Science and Humanities, 20(2), 493-503.

Aminrad, Z., Sayed Zakaria, S. Z. B., \& Hadi, A. S. (2011). Influence of age and level of education on environmental awareness and attitude: Case study on Iranian students in Malaysian Universities. Social Sciences, Vol. 6, pp. 15-19. https://doi.org/10.3923/sscience.2011.15.19

Awan, U., \& Abbasi, A. S. (2013). Environmental Sustainability through Determinism the Level of Environmental Awareness, Knowledge and Behavior among Business Graduates. Research Journal of Environmental and Earth Sciences, 5(9), 505-515. https://doi.org/10.19026/rjees.5.5680

Brilli, F., Fares, S., Ghirardo, A., de Visser, P., Calatayud, V., Muñoz, A., ... Menghini, F. (2018). Plants for Sustainable Improvement of Indoor Air Quality. Trends in Plant Science, 23(6), 507-512. https://doi.org/10.1016/j.tplants.2018.03.004

Citraswari, H., Husein, A., \& Muryoto. (2015). Hubungan Perilaku Penyehatan Udara di dalam Ruang Rumah dan Gangguan Kesehatan Keluarga di Kelurahan Caturtunggal Wilayah Kerja Puskesmas Depok III, Sleman, Yogyakarya. Sanitasi, Jurnal Kesehatan Lingkungan, 6, 157164.

Fitria, L. et al. (2008). Kualitas Udara Dalam Ruang Perpustakaan. 12(2), 76-82.

Ham, M., Horvat, M., \& Mrčela, D. (2015). Insights for Measuring. 159-176.

Jungk, R., \& Muller, N. (1987). Future Workshops : How to create desirable futures. London: Institute of Social Inventions.

Kelly, F. J., \& Fussell, J. C. (2019). Improving indoor air quality, health and performance within environments where people live, travel, learn and work. Atmospheric Environment, 200(November 2018), 90-109. https://doi.org/10.1016/j.atmosenv.2018.11.058

Kencanasari, R. A. V., Surahman, U., \& Permana, A. Y. (2019). The Instrumental Framework to Measuring Environmental Awareness. Innovation of Vocational Technology Education, 15(2), 101. https://doi.org/10.17509/invotec.v15i2.19638

Kencasari, R.A.V.,, Usep surahman, Asep Yudi Permana. (2019). Sick building syndrome: Assessment of school building air quality. Journal of Physics: Conference Series, 1375(1). https://doi.org/10.1088/1742-6596/1375/1/012087

Kencanasari, R. . V., Surahman, U., Permana, A. Y., \& Nugraha, H. D. (2020). Kondisi Kualitas Udara Di Dalam Ruangan Pemukimanan Non-Kumuh Kota Bandung. Jurnal Arsitektur ZONASI, 3(3), 235-245. https://doi.org/10.17509/jaz.v3i3.28134

Kim, J. H., Lee, D., Lim, H., Kim, T., Suk, K., \& Seo, J. (2018). Risk assessment to human health: Consumer exposure to ingredients in air fresheners. Regulatory Toxicology and Pharmacology, 98, 31-40. https://doi.org/10.1016/j.yrtph.2018.05.015

Lu, C., Deng, Q., Li, Y., Sundell, J., \& Norbäck, D. (2016). Science of the Total Environment Outdoor air pollution, meteorological conditions and indoor factors in dwellings in relation to sick building syndrome ( SBS ) among adults in China. Science of the Total Environment, 560-561, 186-196. https://doi.org/10.1016/j.scitotenv.2016.04.033

Mat Said, A., Ahmadun, F. R., Paim, H. L., \& Masud, J. (2003). Environmental Concerns, Knowledge and Practices Gap among Malaysian Teachers. International Journal of Sustainability in Higher Education, 4(4), 305-313. https://doi.org/10.1108/14676370310497534

Mei, N. S., Wai, C. W., \& Ahamad, R. (2016). Environmental Awareness and Behaviour Index for Malaysia. Procedia - Social and Behavioral Sciences, 222(07), 668-675. https://doi.org/10.1016/j.sbspro.2016.05.223

Nugraha, H. D., Poniman, D., Kencanasari, R. A. V., Maosul, A., \& Rusydi, M. I. (2020). MetaAnalisis Model Pembelajaran Vokasi dalam Kondisi Covid-19. Jurnal Dinamika Vokasional Teknik Mesin, 5(2), 83-94. https://doi.org/10.21831/dinamika.v5i2.34779

Permana, A. Y., Farah, A., Permana, S., \& Andriyana, D. (2020). Konfigurasi Ruang Berdasarkan Kualitas Konektivitas Ruangan Dalam Perancangan Kantor : Space Syntax Analysis. Jurnal Arsitektur Zonasi, 3(2), 155-170.

Permana, A. Y., Wijaya, K., Nurrahman, H., \& Permana, A. F. S. (2020). Pengembangan Desain Micro House Dalam Menunjang Program Net Zero Energy Buildings (NZE-Bs). Jurnal Arsitektur ARCADE, 4(1), 73. https://doi.org/10.31848/arcade.v4i1.424

Siswanti, \& Wijayanti, Y. (2018). Faktor Risiko Lingkungan Kejadian Kusta. Higeia(Journal of Public 
Health Research and Development), 2(3), 352-362.

https://doi.org/https://doi.org/10.15294/higeia.v2i3.23619

Takaoka, M., Suzuki, K., \& Norbäck, D. (2016). Sick Building Syndrome among Junior High School Students in Japan in Relation to the Home and School Environment. Global Journal of Health Science, 8(2), 165-177. https://doi.org/10.5539/gjhs.v8n2p165

Takigawa, T., Wang, B., Sakano, N., Wang, D., Ogino, K., \& Kishi, R. (2009). Science of the Total Environment A longitudinal study of environmental risk factors for subjective symptoms associated with sick building syndrome in new dwellings. Science of the Total Environment, The, 407(19), 5223-5228. https://doi.org/10.1016/j.scitotenv.2009.06.023

Trantallidi, M., Dimitroulopoulou, C., Wolkoff, P., Kephalopoulos, S., \& Carrer, P. (2015). EPHECT III: Health risk assessment of exposure to household consumer products. Science of the Total Environment, 536, 903-913. https://doi.org/10.1016/j.scitotenv.2015.05.123

Utami, J. E., Rusmiati, Rokhmalia, F., \& Suprijandani. (2017). Analisis Kandungan Jamur Candida Albicans Terhadap Sanitasi Toilet Umum di Pasar Kota Bojonegoro. Global Health Science, 2(2), 87-90. https://doi.org/10.1016/j.cbpa.2012.10.010

Utari, R. (2011). Taksonomi Bloom Apa dan Bagaimana Menggunakannya? In Widyaiswara Madya, Pusdiklat KNPK (pp. 1-13). https://doi.org/10.1111/j.1365-2427.1976.tb01616.x

Yao, M., \& Zhao, B. (2017). Window opening behavior of occupants in residential buildings in Beijing. Building and Environment, 124(August), 441-449. https://doi.org/10.1016/j.buildenv.2017.08.035 